\title{
Variant Anatomy of the Celiac Trunk and its Branches
}

\author{
Variación Anatómica del Tronco Celíaco y sus Ramas
}

Devi Sankar K.; Sharmila Bhanu P. \& Susan, P. J.

SANKAR, K. D.; BHANU, P. S. \& SUSAN, P. J. Variant anatomy of the celiac trunk and its branches. Int. J. Morphol., 29(2):581-584, 2011.

SUMMARY: The knowledge of abdominal vascular anatomy is very important for surgeons and radiologists to perform many of the clinical diagnostic evaluations. The celiac trunk, one of the branches of the abdominal aorta shows numerous variations in its branching pattern and its branches. The present study is to demonstrate the rare branching pattern of celiac trunk, into hepatogastric and hepatosplenic trunks. The hepatogastric trunk divided into left gastric and accessory left hepatic arteries and the hepatosplenic into common hepatic and splenic artery. The inferior phrenic artery was arising from left gastric artery. The gastroduodenal artery divided into right gastroepiploic artery and a common trunk for right gastric and anterior superior pancreaticoduodenal artery. The posterior superior pancreatico-duodenal artery was arising directly from the gastroduodenal artery and supraduodenal from proper hepatic artery. The variant anatomy of the celiac trunk as found in the present case may be clinically significant during invasive procedures like angiography, chemotherapy, chemoembolization and other surgical conditions of the abdomen.

KEY WORDS: Celiac trunk; Hepatosplenic trunk; Hepatogastric trunk; Accessory hepatic artery.

\section{INTRODUCTION}

The celiac trunk (CT) is one of the short ventral branches of abdominal aorta arising at the level of T12 vertebra. The usual pattern of classical trifurcation of CT into left gastric (LGA), splenic (SA) and common hepatic artery (CHA) is observed in $87.6 \%$ while incomplete division or bifurcation is seen in $12.2 \%$ of individuals, and very rarely complete absence of CT is seen in $0.2 \%$ of cases (Yi et al., 2008). Anatomical variations of CT and its branching pattern, especially the hepatic and left gastric arteries have been reported by many authors (Adachi, 1928; Hiatt et al., 1994; Munshi et al., 2006; Yi et al., 2008; Chen et al., 2009).

In mesenteric arterial system, the extrahepatic arterial bed shows a high degree of variations and these could be identified with precision during the liver harvest. The accurate knowledge of variations of both CT and hepatic artery is essential for general and transplantation surgeons as well as for vascular radiologists because it becomes a technical problem for infusion therapy and transarterial chemoembo-lization of neoplasm in the liver (Chen et al., 1998; Hiatt et al.).

The aim of the present case report is to describe a rare variation of the celiac trunk dividing into hepato-gastric and hepato-splenic trunk and its branches.

\section{CASE REPORT}

During routine undergraduate dissection of the posterior abdominal wall of a 51-year-old male cadaver, the bifurcation of CT was encountered $0.9 \mathrm{~cm}$ after its origin from the abdominal aorta and branched in an unusual manner. CT divided into hepato-gastric and hepato-splenic trunks which the length of $0.6 \mathrm{~cm}$ and $1.4 \mathrm{~cm}$ respectively.

Hepato-gastric trunk divided into larger accessory left hepatic artery (ALHA) and a longer left gastric artery (LGA). As usual LGA ran upwards retroperitoneally towards the esophageal hiatus, giving rise to an esophageal branch, and descended along lesser curvature to anastamose with right gastric artery within the double layered lesser omentum. Before LGA entering into the lesser curvature of stomach, it gave rise to the left inferior phrenic artery.

The larger ALHA ascended upwards and towards right finally reached the left end of porta hepatis of the liver. During the course of ALHA, two gastric branches originated from it and supplied the fundus of stomach.

The hepato-splenic trunk initially ran towards right for a short distance where it divided into common hepatic artery and splenic artery. The splenic artery from hepato- 
splenic trunk coursed towards left side and retroperitoneally along the superior border of pancreas and entered the spleen.

The common hepatic artery (CHA) from hepato-splenic trunk was passing to the right and continued upwards within the right free margin of lesser omentum and in front of the epiploic foramen as proper hepatic artery (PHA) after giving the gastroduodenal artery, and reached the porta hepatis of the liver. Close to porta hepatis, the PHA divided into larger right and smaller left branch of hepatic artery to corresponding lobes of the liver. The right branch of hepatic artery also gave cystic artery to gall bladder. Gastro-duodenal artery (GDA) was arising from the CHA, which runs downwards and bifurcated

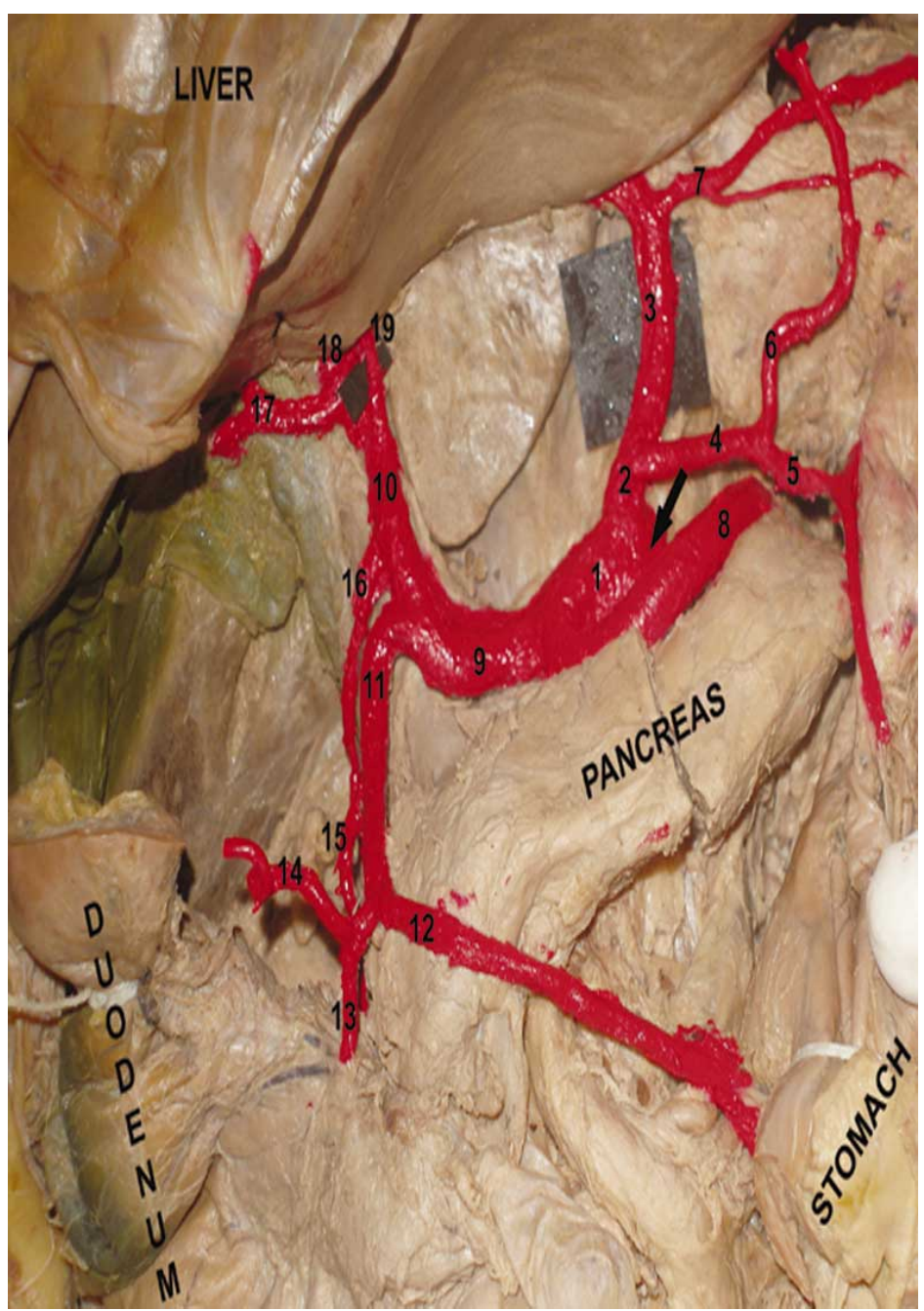

Fig. 1. Dissection of celiac trunk showing the variant pattern of bifurcation and its anomalous branches: Arrow. Celiac trunk; 1 . Hepatosplenic trunk; 2. Hepatogastric trunk; 3. Accessory left hepatic artery; 4\&5. Left gastric artery; 6. Left inferior phrenic artery; 7. Gastric branches; 8. Splenic artery; 9. Common hepatic artery; 10. Proper hepatic artery; 11. Gastroduodenal artery; 12. Right gastro-epiploic artery; 13 . Anterior superior pancreatico-duodenal artery; 14. Right gastric artery; 15. Posterior superior pancreatico-duodenal artery; 16 . Supra-duodenal artery; 17 . Cystic artery; 18 . Right hepatic artery; 19. Left hepatic artery. into right gastro-epiploic artery and a common trunk for right gastric artery and anterior superior pancreatico-duodenal artery. The RGA and right gastroepiploic artery entered the right end of lesser omentum and greater omentum respectively.

Proximal to its bifurcation, the GDA also gave posterior superior pancreatico-duodenal artery. The anterior and posterior superior pancreaticoduodenal arteries were anastamosing with anterior and posterior branches of inferior pancreaticoduodenal artery of superior mesenteric artery as usual. Just $0.4 \mathrm{~cm}$ distal to the emergence of GDA, the PHA gave rise to the supra-duodenal artery which was supplying the first part of the duodenum.

\section{DISCUSSION}

Knowledge of vascular anatomy with its variations is very important to radiologists and surgeons. The celiac trunk and its branches show several variation and has been well documented in literature. The frequency of classical trifurcation of CT was found to be $86 \%$ and bifurcation pattern was $12 \%$. Even though mostly CT divides into CHA, SA, and LGA, sometimes one of its branches may arise from abdominal aorta. Very rarely all the branches of CT arise from the abdominal aorta in case of complete absence of celiac trunk (Yamaki et al., 1995). Hepato-gastric trunk and splenic artery or hepato-splenic trunk and left gastric artery were reported as the branches of abdominal aorta (Vandamme \& Bonte, 1985). The extrahepatic arterial variations are identified with precision at the time of liver surgery or transplantation to avoid injuries that may compromise complete artery ligation. In the present case variations of the branching pattern of $\mathrm{CT}$, the origin of inferior phrenic artery and accessory left hepatic artery were observed, the knowledge of which may be clinically important in the abdominal vascular surgeries, liver transplantation, interventional angiography and other abdominal surgeries.

In the literature the hepato-splenic trunk from CT has been reported by many authors (Adachi; Loukas et al., 2006; Chen et al., 2009; Demirtas et al., 2005). According to Adachi's classification of Type II, the CT gives hepato-splenic trunk and the LGA take its origin directly from the abdominal aorta. The hepato-splenic trunk with an ALHA from 
LGA was reported in type 2a classification of Chen et al. (2009). But in the present study, a different branching pattern of the CT bifurcating into hepato-splenic and hepato-gastric trunks was found. The hepato-gastric trunk got divided into LGA and ALHA and the large hepato-splenic trunk into SA and CHA. The origin of ALHA from the LGA was reported by Hiatt et al. and Michel's (1966) classification but the left gastric artery was arising directly from abdominal aorta in those cases. In the present case the LGA had a common origin with the ALHA from CT, as hepato-gastric trunk which was not found in the any of the classification mentioned in literature.

The most common origin of RGA is from PHA distal to the origin of GDA. The other sites of origin of RGA may be from GDA, common hepatic and RHA. In the present case, GDA terminated into right gastroepiploic artery and a common trunk for RGA and anterior superior pancreaticoduodenal artery. While the posterior superior pancreaticoduodenal artery also termed as retroduodenal artery of Michel's was arising directly from the GDA. Supraduodenal artery which is an inconstant branch usually arises from the GDA or PHA, in this case was arising from PHA (Hollinshead, 1961).

The inferior phrenic arteries (IPA) of right and left side arise as lateral branch from the abdominal aorta, but in the present case, the left IPA arises from the LGA also reported by Pulakunta et al. (2007) and Silveira et al. (2009). During hepato-cellular carcinoma (HCC), the IPA is the most frequent artery establishes the extra-hepatic collateral circulation because this artery is in close contact between the posterior part of liver and diaphragm at the bare area of the liver. If the left lobe is detected for HCC, chemoembolization of left IPA may be preferred. The left IPA may also become a collateral pathway to the stomach. In hepatic arterial infusion chemotherapy, stomach may be perfused with the infused drugs through the left IPA arising from CT or LGA which causes gastric toxicity. In this instance, the embolization of the left IPA may be done to prevent the gastric toxicity (Takeuchi et al., 1998).

Normally any obstruction of CHA proximal to the RGA may save the liver from necrosis due to the collateral circulation between the gastric and gastro-epiploic arteries. When the occlusion affects the PHA, the liver necrosis is invariable. But the presence of ALHA from hepato-gastric trunk as found in present case may reduce or completely avoid necrosis even when the CHA or PHA is occluded because ALHA also supplies the left lobe of the liver.

The primitive splanchnic arteries located in the dorsal mesentery of the gut, gradually fuse to form the arteries of the foregut, midgut and hindgut as CT, superior and inferior mesenteric artery respectively (Sadler, 2000). The persistence or unusual development of ventral splanchnic arteries may result in the variations of CT. The vascular anomalies are usually asymptomatic. Most of the vascular variations are been identified during the clinical diagnostic evaluations or cadaveric studies. The differential branching pattern of $\mathrm{CT}$ and its branches as found in our case may provide additional information for the clinical procedures of diagnostic angiography, transcatheter or chemoembolization therapy and other surgical procedures.

SANKAR, K. D.; BHANU, P. S. \& SUSAN, P. J. Variación anatómica del tronco celíaco y sus ramas. Int. J. Morphol., 29(2):581-584, 2011.

RESUMEN: El conocimiento de la anatomía vascular abdominal es importante para los cirujanos y radiólogos para realizar las evaluaciones de diagnóstico clínico. El tronco celíaco, una de las ramas de la parte abdominal de la aorta presenta numerosas variaciones en su patrón de ramificación y sus ramas colaterales. El presente estudio muestra un raro patrón de ramificación del tronco celíaco, en los troncos hepatogástrico y hepatoesplénico. El tronco hepatogástrico se dividió en las arterias gástrica izquierda y accesoria hepática izquierda, mientras que el hepatoesplénico en las arterias hepática común y esplénica. La arteria frénica inferior se originó desde la arteria gástrica izquierda. La arteria gastroduodenal se dividió en la arteria gastroepiploica derecha y en un tronco común para las arterias gástrica y pancreaticoduodenal anterosuperior. La arteria pancreaticoduodenal posterosuperior se originó directamente de la arteria gastroduodenal y la arteria supraduodenal de la arteria hepática. La variaciónanatómica del tronco celíaco presente en este caso puede ser clínicamente significativa durante procedimientos invasivos como la angiografía, quimioterapia, quimioembolización y afecciones quirúrgicas del abdomen.

PALABRAS CLAVE: Tronco celíaco; Tronco hepatoesplénico; Tronco Hepatogástrico; Arteria hepática accesoria.

\section{REFERENCES}

Adachi, B. Anatomie der Japaner I. Das Arteriensystem der Japaner. Band II. Kaiserlich-Japanischen Universität zu Kyoto. Kyoto, Maruzen, 1928. pp.20-71.
Chen, C. Y.; Lee, R. C.; Tseng, H. S.; Chiang, J. H.; Hwang, J. I. \& Teng, M. M. Normal and variant anatomy of hepatic arteries: angiographic experience. Zhonghua Yi 
Хие Za Zhi, 61(1):17-3, 1998.

Chen, H.; Yano, R.; Emura, S. \& Shoumura, S. Anatomic variation of the celiac trunk with special reference to hepatic artery patterns. Ann. Anat., 191(4):399-407, 2009.

Demirtas, K.; Gulekon, N.; Kurkcuoglu, A.; Yildirim, A. \& Gozil, R. Rare variation of the celiac trunk and related review. Saudi Med. J., 26(11):1809-11, 2005.

Hiatt, J. R.; Gabbay, J. \& Busuttil, R. W. Surgical anatomy of the hepatic arteries in 1000 cases. Ann. Surg., 220(1):50-2, 1994.

Hollinshead, W. H. Anatomy for Surgeons-The thorax, $a b$ domen and pelvis. New York, Hoeber-Harper, 1961. pp.321-30. Vol. 2.

Loukas, M.; Fergurson, A.; Louis, R. G. Jr. \& Colborn, G. L. Multiple variations of the hepatobiliary vasculature including double cystic arteries, accessory left hepatic artery and hepatosplenic trunk: a case report. Surg. Radiol. Anat., 28(5):525-8, 2006.

Michels, N. A. Newer anatomy of the liver and its variant blood supply and collateral circulation. Am. J. Surg., 112(3):337-7, 1966.

Munshi, I. A.; Fusco, D.; Tashjian, D.; Kirkwood, J. R.; Polga, J. \& Wait, R. B. Occlusion of an aberrant right hepatic artery, originating from the superior mesenteric artery, secondary to blunt trauma. J. Trauma, 48(2):3256, 2000 .

Pulakunta, T.; Potu, B. K.; Gorantla, V. R.; Rao, M. S.; Madhyastha, S. \& Vollala, V. R. The origin of the inferior phrenic artery: a study in 32 South Indian cadavers with a review of the literature. J. Vasc. Brasileira, 6(3):225-30, 2007.

Sadler, T. W. Digestive System. Langman's Medical Embryology. ${ }^{\text {th }}$ Ed. Philadelphia, Williams \& Wilkins, 2000. pp.270-30.

Silveira, L. A.; Silveira, F. B. \& Fazan, V. P. Arterial diameter of the celiac trunk and its branches. Anatomical study. Acta Cir. Bras., 24(1):43-7, 2009.

Takeuchi, Y.; Arai, Y.; Inaba, Y.; Ohno, K.; Maeda, T. \& Itai, Y. Extrahepatic arterial supply to the liver: observation with a unified CT and angiography system during temporary balloon occlusion of the proper hepatic artery. Radiology, 209(1):121-8, 1998.
Vandamme, J. P. \& Bonte, J. The branches of the celiac trunk. Acta Anat., 122(2):110-4, 1985.

Yamaki, K.; Tanaka, N.; Matsushima, T.; Miyazaki, K. \& Yoshizuka, M. A rare case of absence of the celiac trunk: The left gastric, the splenic, the common hepatic and the superior mesenteric arteries arising independently from the abdominal aorta. Ann. Anat., 177(1):97-100, 1995.

Yi, S. Q.; Terayama, H.; Naito, M.; Hayashi, S.; Moriyama, H.; Tsuchida, A. \& Itoh, M. A common celiacomesenteric trunk and a brief review of the literature. Ann. Anat., 189(5):482-8, 2007.

Yi, S. Q.; Terayama, H.; Naito, M.; Hirai, S.; Alimujang, S.; Yi, N.; Tanaka, S. \& Itoh, M. Absence of the celiac trunk: case report and review of the literature. Clin. Anat., 21(4):283-6, 2008.

Correspondence to:

Devi Sankar K, MSc Medical Anatomy

Assistant Professor

Department of Anatomy

Narayana Medical College and Superspeciality Hospital, Chinthareddy Palem

Nellore,

Andhra Pradesh, 524 002,

INDIA

Phone: +919490948006

Fax: +91 8612317962

Email: lesanshar@gmail.com

Received: 20-03-2010

Accepted: 17-02-2011 